\title{
Determinants of attitudinal and behavioral loyalty among Vietnamese oversea students: The role of disconfirmation, satisfaction and switching cost
}

\author{
Hiep-Hung Pham ${ }^{1,2 *}$, Sueling Lai ${ }^{1}$, Quan-Hoang Vuong ${ }^{2,3}$, The Cuong Nguyen ${ }^{4}$ \\ ${ }^{1}$ Department of International Business Administration, Chinese Culture University, Taiwan \\ $R O C$ \\ ${ }^{2}$ Centre for Interdisciplinary Social Research, Western University Hanoi (ĐH Thành Tây), \\ Hanoi, Vietnam \\ ${ }^{3}$ Centre Emile Bernheim, Université Libre de Bruxelles, Brussels, Belgium. \\ ${ }^{4}$ School of Management and Marketing, University of Southern Queensland, Australia \\ *Corresponding author; email: phamhunghiep@gmail.com
}

\begin{abstract}
International students are important for higher education since they bring additional income for universities, enhance their ranking and reputation and might become high-qualified manpower for host countries in future. This research aims to extend the current knowledge through investigating the effects of disconfirmation, satisfaction and switching cost on attitudinal and behavioral loyalties of international students. A total of 410 Vietnamese oversea students answered our questionnaire survey. Using structure equation model, this study revealed that the mechanism resulting on attitudinal loyalty and behavioral loyalty of international students are different. While satisfaction is found as a partial mediator of the relationship disconfirmation attitudinal loyalty; switching cost is found as a direct antecedent of behavioral loyalty. This article ends with implications in terms of theory and practice.
\end{abstract}

Keyword: international student, loyalty, disconfirmation, satisfaction, switching cost

\section{Introduction}

Since early 2000s, international student has been identified as a major part of internationalization strategy for many higher education providers. This is due to several benefits that international students might bring to host countries and universities. First, in terms of finance, international students are becoming a significant source of income for governments and universities of host 
countries. For instance, in the end of calendar year 2016, Australia collected 21.96 billion Australian dollars from the contribution of international students, increased by $17.74 \%$ compared to 18.65 billion Australian dollars in the calendar year 2015 (Australian Bureau of Statistics, 2017). Second, in terms of reputation, since many recognized university rankings such as THE or QS utilize international students as one of indicators, all higher education institutions nowadays want to recruit and maintain international students. Third, in terms of human resources, several nations, especially developed ones, nowadays invest in international students to prepare for highly qualified manpower in selected disciplines in the long run. For instance, according to Hanson \& Slaughter (2016), the US offers annually about 20,000 H-1B visas, which subsequently serve as precondition for green card in the next step, specifically for postgraduate degree holders from US institutions in tech sector.

Given the importance of international students, many authors have put efforts to shed light on such issue. We can divide the previous literature on international students into 3 topics. First, a number of prior studies (e.g. Lee, 2014; Maringe \& Carter, 2007; Mazzarol \& Soutar, 2002) tried to investigate the push-pull factors driving the outflow of mobilized students from their homeland to oversea. Second, some other authors (e.g. Guo, Li \& Ito, 2014; Mikal, Yang \& Lewis, 2015) focus on the adaptation process of international students into new countries and new academic environments. Third, some others started to examine how loyalty among international students toward their host countries and universities formulate (e.g. Chen, 2016; Paswan \& Ganesh, 2009).

Among the three above streamlines of research, the third one has received the least attention among previous researchers on international students, compared to the two others. Thus, there is little understanding of what factors drive the loyalty of international students toward their incumbent host countries as well as universities. Specifically, this paper will examine how switching cost interacts with disconfirmation and satisfaction in generating attitudinal and behavioral loyalty among international students. This paper contributes to extend the current knowledge on international student loyalty in two aspects:

- First, while previous studies on international student loyalty all regarded loyalty from one-dimensional perspective i.e. loyalty as continued studying intention (behavioral loyalty); or loyalty as positive word of mouth (attitudinal loyalty), the approach of this 
study is to use dual-dimensional conceptualization of loyalty i.e. considering loyalty from both attitudinal loyalty and behavioral loyalty.

- Second, this paper incorporates the established model of disconfirmation expectation (Oliver, 1993) with the concept of switching cost to explain the variation of international student loyalty. As Kim and Son (2009) argued that the stability of relationship between customers (e.g. international students) and service providers (e.g. higher education institutions) is hardly determined without switching cost, the inclusion of switching cost into this study is necessary but this concept seems to be ignored in previous studies in international student loyalty.

This paper is organized as follows: In the literature review, we would explain the conceptualization of international student loyalty from dual-dimensional approach (i.e. attitudinal loyalty and behavioral loyalty) as well as its determinants, including disconfirmation, satisfaction and switching cost. On the basis of literature review, conceptual model and hypotheses would be drawn in the next section. Next, the research methodology would be introduced with the data collection and research methods. In the result findings and discussion section, all results are analyzed and interpreted consistently with the proposed conceptual model. This paper would end with conclusion, limitations and suggestions for further studies.

\section{Literature review}

\section{Disconfirmation}

The international student loyalty has initially involved in the first determinant: Disconfirmation. This construct is originated from the expectation-disconfirmation theory, as this is used popularly in consumer behavior literature (Fan \& Suh, 2014; Oliver, 1997; Van Ryzin, 2013). Fan \& Suh (2014), Oliver (1980) and Van Ryzin (2013) argued that the expectancydisconfirmation model consists of four constructs: Expectations, performance, disconfirmation and satisfaction. Assuming that all other factors are equal, consumers will be likely to have their positive disconfirmation when their product and/or service performance exceeds expectations or, their neutral disconfirmation if their product and/or service performance equals expectations. On the other hand, their negative disconfirmation will be likely to appear when customers have their product and/or service performance lacks of expectations (Bravo et al., 2017). Thus, 
disconfirmation is a difference between expectations and performance, including such three scales as positive, neutral or negative (Bravo et al., 2017).

In the case of international students, their disconfirmations could be related to expectations and performances of tangible components of higher education services like lecture halls, student service centres, libraries, laboratories, computer rooms, etc. and intangible components of higher education services such as the availability of lecturers and tutors, their expertise, their teaching methods, their attitudes to students, etc. (Padlee \& Reimers, 2015). As explained by Lankton and McKnight (2012, p. 89), disconfirmation is "a subjective post-usage comparison that can result in one thinking performance was better, the same as, or worse than expected". Noticeably, disconfirmation plays an independent role that affects directly on satisfaction (Chih et al., 2012).

\section{Satisfaction}

Based on the analysis of the expectancy-disconfirmation model above, Fan \& Suh (2014), Oliver (2010) and Van Ryzin (2013) continue to confirm that disconfirmation has a close relationship with satisfaction. Alternatively, a consumer who has a positive disconfirmation also gains a higher satisfaction. In contrast, he or she gathers a lower satisfaction if having a negative disconfirmation (Van Ryzin, 2013). However, if there is a neutral disconfirmation, the customer also receives a neutral feeling of "neither satisfaction nor dissatisfaction" (Bravo et al., 2017, p. 435). Hence, satisfaction of customers, according to Chih et al. (2012), is a pleasure feeling of comparing between their expectation and performance of a product or a service. Consumers, who rely on their own experience in positive, neutral or negative disconfirmation stage, also provide their own judgement of satisfaction (Oliver, 1980). For examples:

International students are considered as customers in Australia and therefore, they pay attentions to their satisfactory elements in higher education services, consisting of: Academic services (e.g. engagements between lecturers/tutors and students, knowledge deliveries, study materials, etc); Access (e.g. Conveniences of business opening hours in libraries, laboratories, computer rooms, etc; Ease of use in buildings and facilities, etc); Administrative services (e.g. Interactions between professional and administrative staff and students; Timing and precision of feedback to students' problems; Helpfulness of professional and administrative staff to students, etc); Augmented services (e.g. Foods and drinks available in the canteens, car parks and public 
transports services, etc); Physical evidence (e.g. University buildings, sport grounds, swimming pool, gym and fitness centres, etc); and Courses offered (e.g. the variety of courses and degrees offered by higher educational institutions; the reputations and accreditations of these courses and degrees; the relevance of such courses and degrees to the current market needs, etc) (Padlee \& Reimers, 2015, p. 76).

Likewise, international students in the USA specify their satisfactions in the following satisfactory elements: Background and precollege preparation (e.g. Gender, incomes, English language proficiencies, multi-cultural aspects of American higher education environments, etc); Academic involvement (e.g. Frequency of overseas student interactions with academic staff and faculty; frequency of student interactions with their peers in academic activities; study efforts of international students in classes and time invested in self-study of overseas students outside of classes, etc); Social involvement (e.g. Social interactions between international students and local students, social contacts among overseas students of the same nationality, social networks with international students of other nationalities, etc); and Racial/ethnic diversity involvement (e.g. multi-racial and multi-ethical aspects of overseas students in American higher educational institutions, possibility of discriminations between international students and local students, etc) (Zhou \& Cole, 2017, p. 660). Consequently, international student satisfaction is related closely with international student loyalty because of their post-graduation activities: Alumni registrations, donations, recommendations of their ex-higher educational institutions for prospective students in their home countries, etc (Zhou \& Cole, 2017).

\section{Loyalty}

As explained by Erjavec (2015), customer satisfaction itself is not efficient and effective if this construct is not involved closely with customer loyalty. It is because customer loyalty is expressed as a deep commitment of a customer with the current product or service he or she consumes as well as their intention to continue to buy it in the future (Oliver, 1997). Brown \& Mazzarol (2009) demonstrated that loyal overseas students are willing to: (i) Re-enroll in other courses of the higher education institutions that they have studied previously, despite of the competitiveness from other universities; (ii) Enroll in other different delivery modes of courses (online courses, courses by distance learning, etc); (iii) Refer other prospective students to the educational service quality of universities that they have already studies and; (iv) Provide student 
needs and expectations feedback to their previous higher education institutions. Further, according to Yu \& Kim (2008), international student loyalty makes higher education institutions' income sources become more sustainable due to the increase in their self-financing ability as well as the decrease in the dependence of the State or Federal budget supports. However, Gee et al. (2008) argued that customer loyalty is stimulated by attitude and behavior of the customer for a long period of time. Hence, loyalty should be divided into attitudinal loyalty and behavioral loyalty (Oliver, 1999).

\section{Attitudinal loyalty}

Kaur \& Soch (2012), Jani \& Han (2014), and Kuikka \& Laukkanen (2012) described attitudinal loyalty such as: The encouragement of customers to their relatives and friends to use their loyal products or services; the intention of customers to continue to use these products or services for a long period of time; the willingness of customers to pay a higher price for their loyal brand products or services than others, etc. Hence, Oliver (1999) indicated that attitudinal loyalty represents three out of four phases in the process of loyalty formation, including cognitive, affective and conative stages.

Cognitive stage appears when customers seek the product or service information from various sources (Han et al., 2011). As a consequence, cognitive loyalty develops the customers' comparison between the current product or service such as image, quality, functions, and psychological aspects, etc. and other alternative ones (Oliver, 1999).

Affective stage is drawn from an emotional fulfillment and a positive attitude of a customer from a product or service (Oliver, 1999). It is strongly believed that this emotion is necessary in the attitudinal loyalty formation, because attitudinal loyalty concentrates on psychological characteristics of customers (Han et al., 2011).

Conative stage confirms the customer's intention to commit doing something for reaching a goal (Oliver, 1997). In other words, consumers have a strong committed intention to purchase their specific product or service (Oliver, 1999). This phase can be considered as the greater level compared to the two previous phases, as it is the combination between conative phase of attitudinal loyalty and the action phase of the behavioral loyalty (Han et al., 2011; Han \& Woods, 2014). 
In the case of international education, attitudinal loyalty of international students could be cognitive image of their desired universities, affective assessment of the establishment history and academic reputation of such higher education institutions, conative intention to enroll in their desired courses, etc. (Han \& Woods, 2014).

\section{Behavioural loyalty}

Oliver (1999) suggested that behavioral loyalty includes the final phase in the loyalty formation process: That is an action stage. In the action loyalty, customers act in their own specific way to gain their desired product or service. Alternatively, in this phase, customers focus on their behavioral actions frequently (Han et al., 2011).

Thus, international students might express their behavioral loyalty with practical actions such as their behavioral intention to engage in their chosen universities (e.g. collecting course brochures and student information, etc.) and purchase behavior (e.g. official enrolling in their desired course(s) and doing fee payment for them, etc.) (Han \& Woods, 2014).

\section{Switching cost}

Switching cost occurs when customers change a product or service provider to another and face significant costs of their switching. In other words, consumers incur a switching cost if he or she has already purchased a product or service and changed his or her mind in alternative products or services (Shen \& Su, 2015). Generally, the costs of switching could be the monetary or nonmonetary costs (Nagengast et al., 2014).

As specified by Burnham et al. (2003), switching costs include three recent types: First, switching costs which relate to costs of time, effort, risks, evaluation, learning and set up are called procedural switching costs. Second, switching costs that involve in costs of benefit and financial losses are considered as financial switching costs. Finally, switching costs that base on costs of emotional and psychological discomfort can be seen as relational switching costs. Similarly, some others classified switching costs into other different types, such as: Psychological switching costs and economic switching costs (Marshall et al., 2011) or learning costs, transaction costs and artificial costs (Klemperer, 1987; Nilssen, 1992).

\section{Conceptual model}


As mentioned above, some previous studies have investigated that disconfirmation affects satisfaction significantly. For instances, Schwarz and Zhu (2015) demonstrate that the expectancy-disconfirmation theory (Oliver, 1980) influences satisfaction in the international student context, because the exceeder of international student expectations will lead to the appearance of their disconfirmation positively and increase their satisfaction. Similarly, Huang (2015) suggested that international students might increase their satisfaction by increasing their learning performance or decreasing their expectations. Thus, the first hypothesis is as follow:

H1: Disconfirmation influences satisfaction positively.

Naderian \& Baharun (2015) argued that many previous studies confirm the positive relationships between satisfaction and attitudinal and behavioral loyalty under, however, various product and service scenarios. For example, Yu \& Kim (2008) specifically pointed out that international student satisfaction of higher education institution services impacts on international student loyalty positively. Hence, the second and third hypotheses of international student loyalty are proposed as follows:

H2: Satisfaction influences attitudinal loyalty positively.

H3: Satisfaction influences behavioral loyalty positively.

Many previous studies attempted to verify the relationship between switching cost and customer loyalty in various contexts with some similarities and differences in their findings and discussions (Back and Lee, 2009; Ghazali et al., 2016; Ram \& Wu, 2016; Thatcher and George, 2004; Yen, 2010). For example, Thatcher \& George (2004) and Yen (2010) explained that in some USA e-commerce markets, switching cost influenced customer loyalty positively. Whereas, Ram \& Wu (2016) argue that switching cost by itself had no influence with customer loyalty in Chinese mobile phone market and require further research to clarify the role of switching cost in other settings. Additionally, Back \& Lee (2009) and Ghazali et al. (2016) examined that the relationship between customer satisfaction and customer loyalty in e-retailing and country clubbing was not moderated significantly by switching cost.

As a consequence, many studies have further investigated the relationship between switching cost and customer loyalty by dividing loyalty into attitudinal loyalty and behavioral loyalty 
(Nesset \& Helgesen, 2014; Matos et al., 2009). For instance, Nesset \& Helgesen (2014) discovered that in the airport service setting, switching cost influence customer loyalty positively, but weakly. In contrast, Matos et al. (2009) confirm that switching cost influence customer loyalty significantly in both attitudinal and behavioral loyalty aspects.

These arguments suggest the fourth and fifth hypotheses:

H4: Switching cost influences attitudinal loyalty positively.

H5: Switching cost influences behavioral loyalty positively.

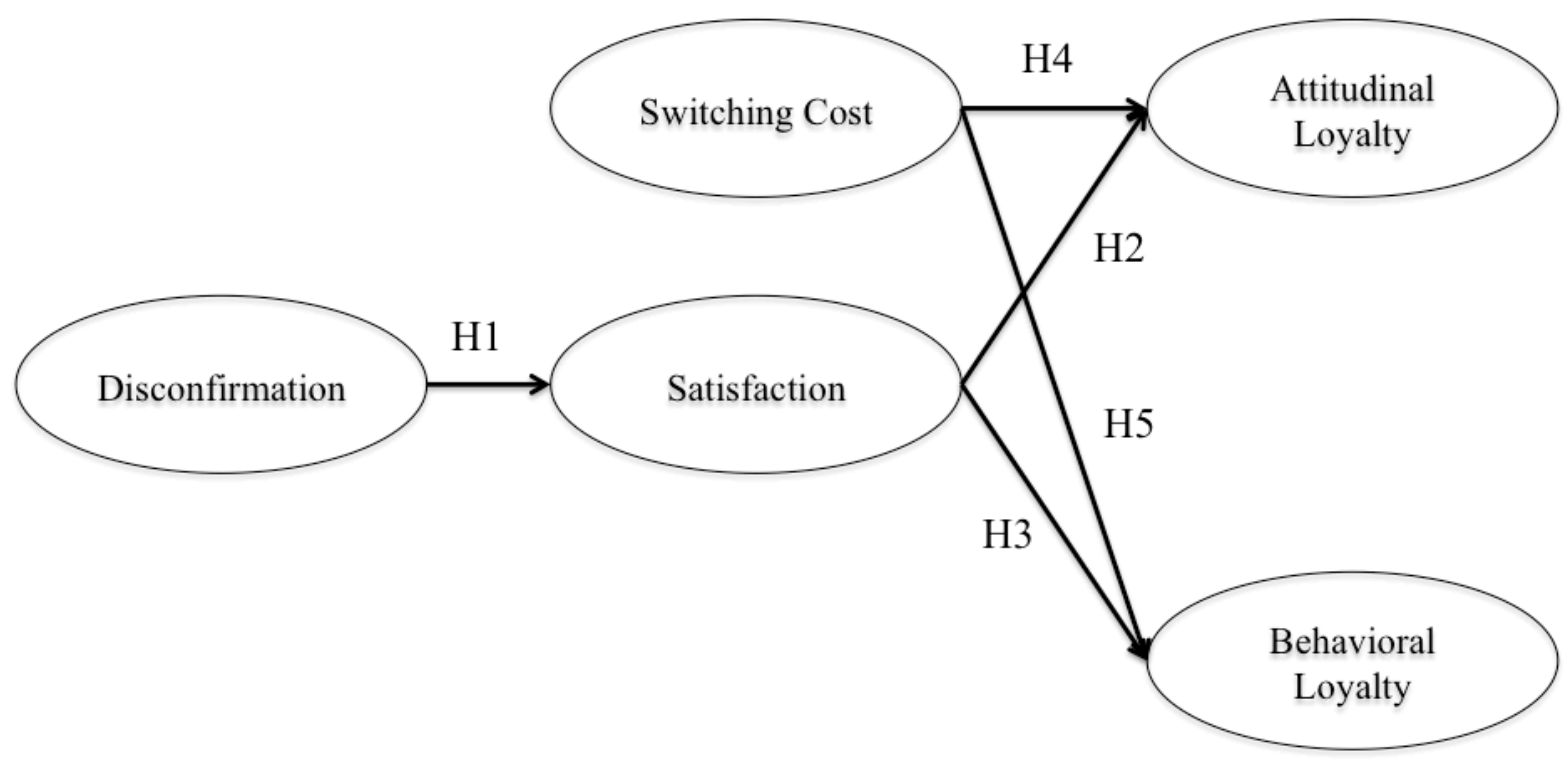

Figure 1. Conceptual model

\section{Research Method}

\section{Survey Questionnaire Development}

The survey questionnaire is composed of two parts: The first aims to collect the demographic and basic profiles of respondents, including: gender, age, current host country, current study program, major, language of instruction in the current study program. In the second part, we 
address questions to measure latent variables introduced in the conceptual model. All questions are adopted from previous highly cited measurements. On the basis of feedbacks: (i) from two experts, one in education and another in marketing fields; and (ii) pilot test with 50 respondents, some necessary adjustments have been conducted in terms of terminology in order to fit with international higher education setting and some items were eliminated due to their low factor loadings (see Table 2). Following suggestion of ..., both Likert scales 5 and 7 were utilized and some questionnaire items are in reversed-code. These actions serve for the purpose of avoiding problem of common method variance.

\section{Data Collection}

Vietnamese oversea students are selected as participants of this study. Vietnam is one of most dynamic sources of international students, according to Choudaha \& Kono (2012). Available data in 2016 showed that there were around 130,000 Vietnamese students, both self-funded and scholarship-received, flying the borders to study offshore (Ha Phuong, 2016). Traditionally, Vietnamese students went to higher developed countries, such as the US, the UK, Australia, Japan and continent European countries seeking for foreign degrees. In recent time, neighboring countries such as Mainland China, Korea or Taiwan ROC have been increasingly selected by Vietnamese students and parents thanks to their geographical proximity and cheaper costs of tuition fee and living expenses. Meanwhile, former Soviet block countries such as Russia or Poland are still receiving stable amounts of Vietnamese students thanks to their former ideological affinity.

We chose two Facebook-based groups gathering Vietnamese oversea students to collect data. A personal solicitation message was sent to 2,000 members randomly picked from these two groups from December 2016 to April 2017. First, the reader was asked whether or not he or she has plan to undertake further study, including bachelor, master, $\mathrm{PhD}$ or post-doc when he or she finishes his or her current program. The reader will only be asked to step into the main questionnaires if his or her answer is "yes".

Eventually, 410 respondents out of 2000 (or 20.5\%) from more than 15 countries across the globe have been validated for the use of data estimation. For 1590 others, 1539 did not answer our questionnaires and 51 others answered but were eliminated due to their incomplete answers. 
Table 1 represents the demographic and basics profiles of our 410 respondents whose answers were utilized for data estimation. 
Characteristic

\begin{tabular}{|c|c|c|}
\hline \multirow{2}{*}{ Characteristic } & \multicolumn{2}{|c|}{ Respondents } \\
\hline & $\begin{array}{c}\text { Frequency } \\
(n=410)\end{array}$ & $\%$ \\
\hline \multicolumn{3}{|l|}{ Gender } \\
\hline Male & 177 & 43 \\
\hline Female & 233 & 57 \\
\hline \multicolumn{3}{|l|}{ Age } \\
\hline Under 20 & 18 & 4 \\
\hline From 20 to 25 & 146 & 36 \\
\hline From 25 to 30 & 146 & 36 \\
\hline From 30 to 35 & 69 & 17 \\
\hline From 35 to 40 & 23 & 6 \\
\hline Over 40 & 8 & 2 \\
\hline \multicolumn{3}{|l|}{ Current host country } \\
\hline \multirow{2}{*}{$\begin{array}{l}\text { Major English-speaking countries (Australia, Canada, New } \\
\text { Zealand, UK, US) } \\
\text { Other countries }\end{array}$} & 208 & 50.7 \\
\hline & 202 & 49.3 \\
\hline \multicolumn{3}{|l|}{ Current study program } \\
\hline Bachelor & 81 & 20 \\
\hline Master and $\mathrm{PhD}$ & 314 & 77 \\
\hline Others & 15 & 4 \\
\hline \multicolumn{3}{|l|}{ Major } \\
\hline Science, technology, engineering and math & 111 & 27 \\
\hline $\begin{array}{l}\text { Economic, business, management, education, pedagogy, foreign } \\
\text { language, linguistic, social science and humanities }\end{array}$ & 271 & 66 \\
\hline Others & 28 & 7 \\
\hline \multicolumn{3}{|l|}{ Language of instruction in the current study program } \\
\hline English & 372 & 91 \\
\hline Others & 38 & 9 \\
\hline
\end{tabular}




\section{Results and Discussion}

\section{Measurement Validation}

For the purpose of measurement validation, CFA was firstly adopted. In table 2, we showcase the results of our multiple fit indices, including chi-square, degree of freedom, goodness of fit (GFI), adjusted goodness of fit (AGFI), normed fit index (NFI), root mean square error of approximation (RMSEA), and Bentler comparative fit index (BCFI). As indicated in Table 2, all multiple fit indices obtained from our estimation are satisfied.

Table 2. Results of multiple fit indices

\begin{tabular}{lll}
\multicolumn{1}{c}{ Index } & Result & Acceptable level \\
\hline Chi-square & 70.49 & - \\
Degree of freedom & 55 & $<$ \\
Chi-square/ Degree of freedom & 1.28 & $>5$ \\
GFI & 0.97 & $>0.9$ \\
AGFI & 0.96 & $>0.8$ \\
NFI & 0.96 & $>0.9$ \\
RMSEA & 0.03 & $<0.08$ \\
BCFI & 0.99 & $>0.9$ \\
\hline
\end{tabular}

The items' standardized factor loading, construct reliability (CR), and average variance extracted (AVE) scores are selected to access whether or not convergent validity is problematic for this study. As indicated in Table 3, all factor loadings for individual items are higher than 0.7 (except SAT3, SWC1 and ALO1's are higher than 0.5). According to Evanschitzky, Iyer, Plassmann, Niessing \& Meffert (2006), minimum acceptable level of standardized factor loading is 0.5 and preferred level is 0.7. All CRs and AVEs are satisfied, as their scores are all higher than cutoff points ( 0.7 and 0.5 , respectively). Last but not least, since our estimation indicated that AVE scores are higher the correlations between the latent variables, discriminant validity is demonstrated as not a problem for our study. 
Disconfirmation: Likert scale 7 (Liao et al., 2007)

DIS1: Your experience with studying at the current university and living in the current host country is worse than what you expected before (reverse code)

DIS2: The education provided by your current university and the living conditions and environments provided by your current host country are better than what you expected before

Satisfaction: Likert scale 7 (Liao et al., 2007)

Overall, how do you feel about the service provided to you by your current university and the life in the current host country?

SAT1: Satisfied

SAT2: Pleased

Switching Cost: Likert scale 5 (Ping, 1993)

SWC1: Generally speaking, the costs in time, money, effort, and grief to switch from your current host country to another country for further study would be high

SWC2: Overall, You would spend a lot and lose a lot if you switched from current host country to another country for further study

Behavioral Loyalty: Likert scale 7 (Oliver \& Swan, 1989)

Rate the PROBABILITY that you would MOVE to another foreign country for further study (reverse code) 
BLO1: Likely

BLO2: Probable

BLO3: Certain
0.83

0.92

0.73

26.95

Attitudinal Loyalty: Likert scale 5 (Hennig-Thurau et al., 2001)

ALO1: You will say positive things about universities in the current host country to other people

ALO2: You will recommend the current host country to someone seeking your advice for education service

ALO3: You will encourage your friends/relatives to study in the current host country

Table 4. Convergent and Discriminant Validity

\begin{tabular}{cccccccc}
\hline \multirow{2}{*}{ Construct } & CR & AVE & \multicolumn{5}{c}{ Factor correlation } \\
\cline { 3 - 7 } & & & DIS & SAT & SWC & BLO & ALO \\
\cline { 4 - 7 } DIS & 0.87 & 0.77 & 1 & & & \\
\hline SAT & 0.83 & 0.63 & 0.61 & 1 & & \\
\hline SWC & 0.63 & 0.47 & 0.02 & 0.02 & 1 & \\
\hline BLO & 0.87 & 0.70 & 0.51 & 0.02 & 0.19 & 1 & \\
\hline ALO & 0.84 & 0.64 & 0.05 & 0.49 & 0.01 & 0.02 & 1 \\
\hline
\end{tabular}

DIS: Disconfirmation; SAT: Satisfaction; SWC: Switching Cost; BLO:

Behavioral Loyalty; ALO: Attitudinal Loyalty 


\section{Model testing}

The Structural Equation Model was employed to test the proposed hypotheses in this study. Table 5 and Figure 2 indicate the results of our data estimation. Specifically, all multiple fit indices, including chi-square, degree of freedom, goodness of fit (GFI), adjusted goodness of fit (AGFI), normed fit index (NFI), comparative fit index (CFI), root mean square error of approximation (RMSEA), and Bentler comparative fit index (BCFI) as shown in Table 5 demonstrate the appropriateness between the conceptual model and the empirical data. Regarding path analyses, among five hypothetical paths, three were supported with empirical results while two were not. Therefore, H1 (Disconfirmation - Satisfaction), H2 (Satisfaction Attitudinal Loyalty) and H5 (Switching Cost - Behavioral Loyalty) are confirmed and H3 (Satisfaction - Behavioral Loyalty) and 4 (Switching Cost - Attitudinal Loyalty) were not. In addition, on the basis of modification index results, a new path from Disconfirmation to Attitudinal Loyalty was revealed. In terms of variance explained, 31.41\% variance of Attitudinal Loyalty is explained by our model, the corresponding figures for Behavioral Loyalty and Satisfaction are $4.1 \%$ and $37.33 \%$, respectively.

The confirmation of H1 (Disconfirmation - Satisfaction) and H2 (Disconfirmation Attitudinal Loyalty) are in line with several previous studies, which also employed disconfirmation - expectancy model in different settings e.g. tourism (Hui, Wan \& Ho, 2007), haircut service (Maxham III, 2001). In higher education in particular, Casidy \& Wymer (2015) surveyed 948 Australian also released similar result regarding path from Satisfaction to Attitudinal Loyalty with our study. Thus, the more actual educational performance perceived by international students exceeding the prior expectations, the more they satisfy and thus the more loyal they become regarding attitudinal dimension.

However, our empirical results indicated that there is not significant impact of satisfaction on Behavioral Loyalty (H3). There are two possible ways to explain this finding. First, as Mittal \& Kamakura (2001)'s finding, satisfaction - behavioral loyalty might not be a linear relationship, but non-linear. This does mean that Satisfaction still influences positively on Behavioral Loyalty but not in a linear pattern. Given that method used in this study (SEM) is only workable with 
linear estimation, rejection of $\mathrm{H} 3$ is plausible. Second, alternative explanation for this finding stems from a proposition of Oliver (1999). In his conceptual work, Oliver (1999) asserted that high satisfaction would not universally and necessarily translates into loyalty. Among identified reasons that obstruct loyalty, change in need is a common reason. For instance, as a child grows up, his or her old toys may not match with the new demand of the new development's pace. In this circumstance, although he or she may still like the toy (high attitudinal loyalty), he or she eventually does not play with it (low behavioral loyalty). In the same vein with this above situation, it is likely that an international student, after finishing his or her first degree oversea, still has high attitudinal loyalty towards his or her current host country; but as he or she changes the need and does not want to stay in the same country for further study anymore. In other words, in both two above cases, as a consumer (a child consuming toy or a student consuming oversea education) has matured; his or her high satisfaction does not automatically translate into behavioral loyalty (re-play the toy or stay in the same country for further study). A similar phenomenon was also observed within working organization. Mosadeghrad, Ferlie, \& Rosenberg (2008), in a study with 629 employees of a hospital at Iran revealed that there is a positive association between the degree of staff's satisfaction with their turnover intention. This may be due to a "changing need" situation in which the more satisfied an employee is, the more likely he or she changes his/her need, and thus the more likely, he or she wants to quit his/her incumbent job.

Regarding the association between Disconfirmation and Attitudinal Loyalty, as mentioned earlier, we have revealed a new direct path starting from Disconfirmation and ending at Attitudinal Loyalty. This finding, indeed, is consistent with certain existing literature in relationship marketing in general. For instance, Caro \& García (2007) also founded a significantly direct impact of disconfirmation on loyalty in sport event context. On the light of this empirical result, it's suggested that within international higher education context, disconfirmation does not only play a role of indirect antecedent of loyalty but also a direct one.

As discussed earlier, given the special attributes of higher education service, Switching Cost should be considered as a key determinant of student loyalty. And our data estimation demonstrated partly the hypothesized role of Switching Cost. In particular, Switching Cost was found to have a significant impact on Behavioral Loyalty, but not Attitudinal Loyalty. 
Table 5. Results of Structural Equation Model

\begin{tabular}{|c|c|c|c|}
\hline & $\beta$ coefficient & t value & Hypothesis \\
\hline \multicolumn{4}{|c|}{ Dependent variable: Satisfaction } \\
\hline Disconfirmation & 0.61 & 15.56 & H1 supported \\
\hline $\mathrm{R}^{2}$ & $37.33 \%$ & & \\
\hline \multicolumn{4}{|c|}{ Dependent variable: Behavioral Loyalty } \\
\hline Switching Cost & 0.19 & 2.82 & H5 supported \\
\hline Satisfaction & 0.07 & 1.00 & H3 not supported \\
\hline $\mathrm{R}^{2}$ & $4.10 \%$ & & \\
\hline \multicolumn{4}{|c|}{ Dependent variable: Attitudinal Loyalty } \\
\hline Switching Cost & 0.00 & 0.01 & H4 not Supported \\
\hline Satisfaction & 0.28 & 4.30 & H2 supported \\
\hline Disconfirmation & 0.34 & 5.25 & Newly revealed path \\
\hline 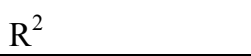 & $31.41 \%$ & & \\
\hline
\end{tabular}

\section{Conclusion}

This study contributes to the scant literature on loyalty of international students and its antecedents. Specifically, this study incorporate components of disconfirmation expectation model with switching cost into a framework to predict and explain two sub-dimensions of international student loyalty: attitudinal loyalty and behavioral loyalty.

\section{Theoretical Implications}

The findings, evoked from a survey conducted with 410 Vietnamese oversea students from over 15 countries across the world, demonstrated that components of disconfirmation expectation model, including disconfirmation and satisfaction are significant determinants of attitudinal loyalty, but not behavioral loyalty. Specifically, our empirical results showed that disconfirmation has both direct and indirect (via satisfaction) impact while satisfaction has only 
direct impact on attitudinal loyalty. Meanwhile, switching cost is found to have a direct impact on behavioral loyalty, but not on attitudinal loyalty. These findings imply that the mechanisms leading to two sub-dimensions of loyalty (i.e. attitudinal and behavioral) might be different. In other words, an international student having high behavioral loyalty toward his or her incumbent host country does not necessarily have high attitudinal loyalty, and vice-versa. On the basis of this assertion and on the basis of Backman \& Crompton (1991)'s typology, it would be possible to divide international student loyalty into 4 clusters with different loyal behaviors. These are (i) True Loyalty: (international) students demonstrate their high degree of behavioral loyalty as well as psychological bonding (attitudinal loyalty) toward their current host countries (ii) True Disloyalty: (international students) showcase contrast features to the high loyalty; (iii) Spurious Loyalty: students have intention to continue to study at the current host countries but with low level of attachment (low attitudinal loyalty) and (iv) Latent Loyalty: individuals prefer to stick with their current host countries but have intention to switch due to certain situational factors.

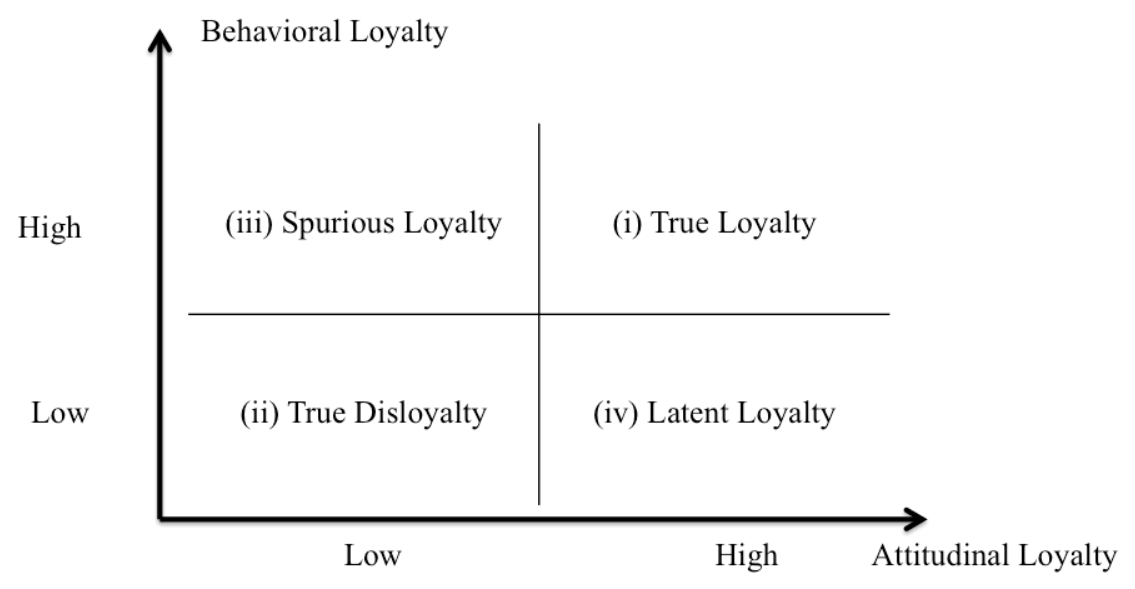

Figure 2: Four clusters of international student loyalty

Source: authors adopted and adjusted from Backman \& Crompton (1991)

\section{Managerial Implications}

A number of implications might be withdrawn for policy makers and universities' managers on the basis of our empirical findings. First, it's suggested that attitudinal loyalty and behavioral loyalty are formulated in two different ways. Attitudinal loyalty in international higher education setting is important because: (i) this will lead to positive word-of-mouth i.e. international 
students would say positive things about their current host countries and universities and recommend their relatives and friends about their current host countries and universities for education purpose; and (ii) this will ensure a strong emotional bond between international students and host countries, universities and professors etc. In order to enhance attitudinal loyalty among, policy makers and universities' leaders might focus on effort to enhance disconfirmation and subsequently satisfaction of international students.

Behavioral loyalty of international students is also important as it brings direct benefits for host countries and universities such as income from tuition fee for further study; diversity of international environment, qualified human resources with cheap costs (in case international students are at graduate level or above) etc. Among different measures, enhancing switching cost is one that may result in increase of attitudinal loyalty. Providers in other service settings have employed a number of actions in order to enhance switching cost. For instance, in airline service, airline firms often use membership cards as measure to enhance switching cost among customers, thus enhance behavioral loyalty (Gudmundsson, de Boer \& Lechner, 2002). In the same vein, higher education providers might introduce similar "membership" programs for their international students i.e. international students undertake their second degrees at the incumbent universities would be get tuition reduction or waive.

\section{Limitations and Recommendations for Future Researches}

Future studies might have a number of areas for research on the basis of limitations of this study. First, despite participants in this study cover over 15 countries across the world; they are somewhat bias in terms of educational level. As indicated in Table 1,77\% participants of this study are at graduate level. This figure is, indeed, reasonable as the two Facebook groups that the survey was delivered gathered mostly graduate students. However, this might not reflect the actual profile of Vietnamese oversea students' population. Other authors might overcome this limitation by selecting sample balancing between undergraduate and graduate students.

Second, despite the idea that classifies international students into four clusters i.e. true loyalty, true disloyalty, latent loyalty and spurious loyalty as explained in theoretical implication is interesting, this study could not identify attributes and behaviors pertaining to each cluster. It is because the antecedents included in this study are not sufficient to explain all the variations of 
the two exogenous variables i.e. attitudinal loyalty and behavioral loyalty. The future studies might build a more comprehensive model than this current study and thus, attributes of international students corresponding with each above cluster might be identified. As these attributes are identified, a number of implications in terms of theory and practice would be withdrawn, with no doubt.

\section{Acknowledgement}

The authors would like to thank Ms. Nguyen Dieu Cuc, Institute of Education Science, Justus Liebig University of Giessen, Germany for her valuable comments on the earlier version this article.

\section{References}

Australian Bureau of Statistics. (2017). International Trade in Services: Supplementary Information, Calendar Year, 2016.

Back, K. J. \& Lee, J. S. (2009). Country club members' perceptions of value, image congruence, and switching cost: An exploratory study of country club members' loyalty. Journal of Hospitality \& Tourism Research, 33(4), 528-546.

Backman, S. J., \& Crompton, J. L. (1991). Differentiating between High, Spurious, Latent, and Low Loyalty Participants in Two Leisure Activities. Journal of Park and Recreation Administration, 9(2), 1-17.

Bravo, M. I. R., Montes, F. J. L. \& Moreno, A. R. (2017). Open innovation in supply networks: an expectation disconfirmation theory perspective. Journal of Business \& Industrial Marketing, 32(3), 432-444.

Brown, R. M., \& Mazzarol, T. W. (2009). The importance of institutional image to student satisfaction and loyalty within higher education. Higher Education, 58(1), 81-95.

Burnham, T., Frels, J. \& Mahajan, V. (2003). Consumer switching costs: a typology, antecedents, and consequences. Journal of the Academy of Marketing Science, 31(2), 109-126.

Canadian Bureau of International Education. (2017). Facts at a Glance. Retrieved from http://cbie.ca/ 
Caro, L. M., \& García, J. A. M. (2007). Cognitive-affective model of consumer satisfaction. An exploratory study within the framework of a sporting event. Journal of Business Research, 60(2), 108-114.

Casidy, R., \& Wymer, W. (2015). The impact of brand strength on satisfaction, loyalty and WOM: An empirical examination in the higher education sector. Journal of Brand Management, 22(2), 117-135.

Chen, Y.-C. (2016). The Drive Behind International Student Loyalty in HigherEducational Institutions: A Structural Equation Model. Asia-Pacific Education Research, 25(2), 315-323.

Chih, W.-H., Wang, K.-Y., Hsu, L.-C. and Cheng, I.-S. (2012). From disconfirmation to switching: an empirical investigation of switching intentions after service failure and recovery. The Service Industries Journal, 32(8), 1305-1321.

Cho, J. \& Lee, S. (2016). International Students' Proactive Behaviors in the United States: Effects of Information-Seeking Behaviors on School Life. Journal of College Student Development, 57(5), 590-603.

Choudaha, R., \& Kono, Y. (2012). Beyond More of the Same: the top four emerging markets for international student recruitment. World Education News \& Reviews. Retrieved from: https://wenr.wes.org/2012/10/wenr-october-2012-beyond-more-of-the-same-top-four-emerging-marketsfor-international-student-recruitment

Erjavec, H. Š . (2015). Customer satisfaction and customer loyalty within part-time students. Journal of Economics and Economic Education Research, 16(2), 1-17.

Evanschitzky, H., Iyer, G. R., Plassmann, H., Niessing, J., \& Meffert, H. (2006). The relative strength of affective commitment in securing loyalty in service relationships. Journal of Business Research, 59(12), 1207-1213.

Fan, L. \& Suh, Y-H. (2014). Why do users switch to a disruptive technology? An empirical study based on expectation-disconfirmation theory. Information \& Management, 51, 240-248.

Finn, M. \& Darmody, M. (2017). What predicts international higher education students' satisfaction with their study in Ireland?. Journal of Further and Higher Education, 41(4), 545555. 
Ghazali, E., Nguyen, B., Mutum, D. S. \& Mohd-Any, A. A. (2016). Constructing online switching barriers: examining the effects of switching costs and alternative attractiveness on estore loyalty in online pure-play retailers. Electron Markets, 26, 157-171.

Gee, R., Coates, G. \& Nicholson, M. (2008). Understanding and profitably managing customer loyalty. Marketing Intelligence \& Planning, 26(4), 359-373.

Gudmundsson, S. V., de Boer, E. R., \& Lechner, C. (2002). Integrating frequent flyer programs in multilateral airline alliances. Journal of Air Transport Management, 8(6), 409-417.

Guo, Y., Li, Y., \& Ito, N. (2014). Exploring the predicted effect of social networking site use on perceived social capital and psychological well-being of Chinese international students in Japan. Cyberpsychology, Behavior, and Social Networking, 17(1), 52-58.

Ha Phuong (2016). Vietnamese oversea students mostly stay in Japan. Retrieved from: http://vietnamnet.vn/vn/giao-duc/du-hoc/du-hoc-nhat-ban-du-hoc-my-du-hoc-sinh-viet-nam-dong-nhat-onhat-337144.html

Han, H., Kim, Y., \& Kim, E. (2011). Cognitive, affective, conative, and action loyalty: Testing the impact of inertia. International Journal of Hospitality Management, 30(4), 10081019.

Han, H. \& Woods, D. P. (2014). Attitudinal and Behavioral Aspects of Loyalty in the Screen-Golf Industry. Journal of Quality Assurance in Hospitality \& Tourism, 15(2), 175-189.

Hanson, G. H., \& Slaughter, M. J. (2016). High-skilled immigration and the rise of STEM occupations in US employment (No. w22623). National Bureau of Economic Research.

Huang, H. H. (2015). The Probability Model of Expectation Disconfirmation Process. Expert Journal of Marketing, 3(1), 11-16.

Hui, T. K., Wan, D., \& Ho, A. (2007). Tourists' satisfaction, recommendation and revisiting Singapore. Tourism management, 28(4), 965-975.

Izogo, E. E. (2016). Antecedents of attitudinal loyalty in a telecom service sector: the Nigerian case. International Journal of Quality \& Reliability Management, 33(6), 747-768.

Jani, D. \& Han, H. (2014). Personality, satisfaction, image, ambience, and loyalty: testing their relationships in the hotel industry. International Journal of Hospitality Management, 37, 11-20.

Kaur, H. \& Soch, H. (2012). Validating antecedents of customer loyalty for Indian cell phone Users. Vikalpa, 37(4), 47-61. 
Kim, S.S. \& Son, J.-Y. (2009). Out of dedication or constraint? A dual model of postadoption phenomena and its empirical test in the context of online services. MIS Quarterly, 33(1), 49-70.

Klemperer, P. (1987). Markets with Consumer Switching Costs. Quarterly Journal of Economics, 102(2), 375-394.

Kuikka, A. \& Laukkanen, T. (2012). Brand loyalty and the role of hedonic value. Journal of Product \& Brand Management, 21(7), 529-537.

Lam, S. Y., Shankar, V., Erramilli, M. K., and Murthy, B. (2004). Customer value, satisfaction, loyalty, and switching costs: An illustration from a business-to-business service context. Journal of the Academy of Marketing Science, 32, 293-311.

Lankton, N.K. and McKnight, H.D. (2012). Examining two expectation disconfirmation theory models: assimilation and asymmetry effects. Journal of the Association for Information Systems, 13(2), 88-115.

Lee, C. F. (2014). An investigation of factors determining the study abroad destination choice: A case study of Taiwan. Journal of Studies in International Education, 18(4), 362-381.

Maringe, F., \& Carter, S. (2007). International students' motivations for studying in UK HE: Insights into the choice and decision making of African students. International Journal of Educational Management, 21(6), 459-475.

Marshall, R., Tzung-Cheng, H., Yingzi, X. and Inwoo, N. (2011). Extending Prospect Theory Cross-Culturally by Examining Switching Behavior in Consumer and Business-toBusiness Contexts. Journal of Business Research, 64(8), 871-878.

Matos, C. A. D., Henrique, J. L. \& Rosa, F. D. (2009). The different roles of switching costs on the satisfaction loyalty relationship. International Journal of Bank Marketing, 27(7), 506-523.

Maxham III, J. G. (2001). Service recovery's influence on consumer satisfaction, positive word-of-mouth, and purchase intentions. Journal of business research, 54(1), 11-24.

Mazzarol, T., \& Soutar, G. N. (2002). "Push-pull" factors influencing international student destination choice. International Journal of Educational Management, 16(2), 82-90.

Mittal, V., \& Kamakura, W. A. (2001). Satisfaction, repurchase intent, and repurchase behavior: Investigating the moderating effect of customer characteristics. Journal of marketing research, 38(1), 131-142. 
Mikal, J. P., Yang, J., \& Lewis, A. (2015). Surfing USA: How Internet use prior to and during study abroad affects Chinese students' stress, integration, and cultural learning while in the United States. Journal of Studies in International Education, 19(3), 203-224.

Mosadeghrad, A. M., Ferlie, E., \& Rosenberg, D. (2008). A study of the relationship between job satisfaction, organizational commitment and turnover intention among hospital employees. Health services management research, 21(4), 211-227.

Naderian, A. \& Baharun, R. (2015). Service Quality and Consumer Satisfaction and Loyalty association Moderated by Switching Cost in Hospitality Industry. International Journal of Hospitality \& Tourism Systems, 8(1), 10-22.

Nagengast, L., Evanschitzky, H., Blut, M. \& Rudolph, T. (2014). New Insights in the Moderating Effect of Switching Costs on the Satisfaction-Repurchase Behavior Link. Journal of Retailing 90(3), 408-427.

Nesset, E. \& Helgesen, Ø. (2014). Effects of switching costs on customer attitude loyalty to an airport in a multi-airport region. Transportation Research Part A, 67, 240-253.

Nilssen, T. (1992). Two Kinds of Consumer Switching Costs. The RAND Journal of Economics, 23(4), 579-589.

Oliver, R. L. (1980). A cognitive model of the antecedents and consequences of satisfaction decisions. Journal of Marketing Research, 42, 460-469.

Oliver, R. L. (1993). Cognitive, affective, and attribute bases of the satisfaction response. Journal of consumer research, 20(3), 418-430.

Oliver, R. L. (1997). Satisfaction: A behavioral perspective on the consumer. New York: Irwin McGraw-Hill.

Oliver, R. L. (1999). Whence consumer loyalty? Journal of Marketing, 63, 33-34.

Oliver, R. L. (2010). Satisfaction. New York, NY: M.E. Sharpe.

Oliver, R. L., \& Swan, J. E. (1989). Consumer perceptions of interpersonal equity and satisfaction in transactions: a field survey approach. The Journal of Marketing, 21-35.

Paswan, A. K., \& Ganesh, G. (2009). Higher education institutions: Satisfaction and loyalty among international students. Journal of Marketing for Higher Education, 19(1), 65-84. 
Padlee, S. F. \& Reimer, V. (2015). International student satisfaction with, and behavioural intentions towards, universities in Victoria, Journal of Marketing for Higher Education, 25(1), 70-84.

Ping Jr, R. A. (1993). The effects of satisfaction and structural constraints on retailer exiting, voice, loyalty, opportunism, and neglect. Journal of retailing, 69(3), 320-352.

Quintal, V. \& Phau, I. (2016). Comparing student loyalty behavioural intentions across multi entry mode deliveries: An Australian perspective. Australasian Marketing Journal, 24, $187-197$.

Ram, J. \& Wu, M. L. (2016). A fresh look at the role of switching cost in influencing customer loyalty: Empirical investigation using structural equation modelling analysis. Asia Pacific Journal of Marketing and Logistics, 28(4), 616-633.

Russell-Bennett, R., McColl-Kennedy, J.R. \& Coote, L.V. (2013). Involvement, satisfaction, and brand loyalty in a small business services setting. Journal of Business Research, $60(12), 1253-1260$.

Schwarz, C. \& Zhu, Z. (2015). The Impact of Student Expectations in Using Instructional Tools on Student Engagement: A Look through the Expectation Disconfirmation Theory Lens. Journal of Information Systems Education, Vol. 26(1), 47-58.

Shen, N. \& Su, J. (2015). A comparison of different contract forms for consumers with switching costs and changed preferences. Economic Modelling 50, 19-26.

Smith, C. (2016). International Student Success. Strategic Enrollment Management Quarterly, 4(2), 61-73.

Tarus, D. K. \& Rabach, N. (2013). Determinants of customer loyalty in Kenya: does corporate image play a mediating role?. The TQM Journal, 25(5), 473-491.

Thatcher, J. B. \& George, J. F. (2004). Commitment, trust, and social involvement: an exploratory study of antecedents to web shopper loyalty. Journal of Organizational Computing and Electronic Commerce, 14(4), 243-268.

Van Ryzin, G. G. V. (2013). An Experimental Test of the Expectancy-Disconfirmation Theory of Citizen Satisfaction. Journal of Policy Analysis and Management, 32(3), 597-614.

Yen, Y. S. (2010). Can perceived risks affect the relationship of switching costs and customer loyalty in e commerce?. Internet Research, 20(2), 210-224. 
Yu, G. B. \& Kim, J.-H. (2008). Testing the mediating effect of the quality of college life in the student satisfaction and student loyalty relationship. Applied Research in Quality of Life, $3(1), 1-21$.

Zhou, J. \& Cole, D. (2017). Comparing international and American students: involvement in college life and overall satisfaction. High Education, 73, 655-672. 